\title{
Effect of Steaming and Dehydration Condition on Physicochemical Characteristics of Korean Traditional Parboiled Rice (Olbyeossal)
}

\author{
Yong Sik Cho $\cdot$ Kyoung Ha Lee $\cdot$ Hyun Ji Ha $\cdot$ Yoon Hee Choi $\cdot$ Eun Mi Kim $\cdot$ Shin Young Park
}

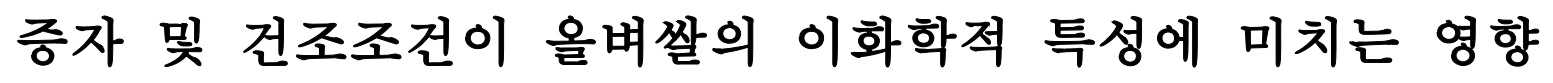

조용식 · 이경하 · 하현지 · 최윤희 · 김은미 · 박신영

Received: 4 November 2011 / Accepted: 4 July 2012 / Published Online: 30 September 2012

(C) The Korean Society for Applied Biological Chemistry 2012

\begin{abstract}
This study was conducted to investigate the effect of different steam condition and dehydration condition on physicochemical characteristics of Olbyeossal made from Waxy rice. All samples were steamed at $95-100^{\circ} \mathrm{C}$ for $60 \mathrm{~min}$ or at $121^{\circ} \mathrm{C}$ for $20 \mathrm{~min}$ and then were dehydrated using hot air 45,60 , $80^{\circ} \mathrm{C}$ and sun-dried to achieve moisture contents $13-15 \%$. Initial pasting temperature of Olbyeossal was the lower than that of nontreatment sample by parboiling. The combination in steaming 95 $100^{\circ} \mathrm{C}$ and hot drying at $45-60^{\circ} \mathrm{C}$ was showed appropriate pasting properties compared with other condition. The hardness of Olbyeossal was significantly affected by steaming and dehydration condition. The hardness of Olbyeossal showed the higher value for steaming at $121^{\circ} \mathrm{C}$ than $95-100^{\circ} \mathrm{C}$. The water binding capacity (WBC) and swelling power (SP) were higher steaming at $121^{\circ} \mathrm{C}$ than $95-100^{\circ} \mathrm{C}$. No significant differences on WBC and SP of Olbyeossal by dehydration condition were observed. As the sensory evaluation results, the combination in steaming at $121^{\circ} \mathrm{C}$ and hot-air drying at 45 or $80^{\circ} \mathrm{C}$ led to increase preference for appearance, color, taste and overall acceptability. These results indicate that steaming and dehydration condition were affecting factor on physicochemical characteristics of Olbyeossal.
\end{abstract}

Keywords dehydration · steaming $\cdot$ Olbyeossal $\cdot$ physicochemical characteristics $\cdot$ sensory evaluation

\section{Y. S. Cho $(\bowtie)$}

Agro-food Utilization Division, National Academy of Agricultural Science, Rural Development Administration, Suwon 441-853, Republic of Korea E-mail: yscho@korea.kr

Y. S. Cho · K. H. Lee · H. J. Ha · Y. H. Choi · E. M. Kim · S. Y. Park Fermented Food Science Division, National Academy of Agricultural Science, Rural Development Administration, Suwon 441-853, Republic of Korea
서 론

쌀은 우리나라의 주곡작물로서 소비량이 점차 줄고 있어 가공 기술을 접목하여 다양화 할 필요가 있다. 파보일미는 동남아시 아나 아프리카 등지에서 벼를 물에 침지, 증자, 건조하여 도정 한 대표적인 가공 쌀의 일종으로 일반 주식용 이외에도 각종 쌀 요리, 통조림 제품, 팽화제품으로 만드는 데 다용도로 이용 되고 있다(Burn, 1972). 벼의 파보일링은 당초 왕겨의 제거를 용이하게 하기 위한 목적에서 고안되었으나(Gariboldi, 1974) 벼 의 완전립 수율의 증가(Bhattacharya, 1977), 도정수율의 증가 (Filho, 1986), 손상 또는 젖은 벼의 구제 등 경제성 외에도 파 보일링에 의한 쌀의 영양가 개선 등 영양적 장점이 알려지면서 급속하게 성장하게 되었다.

파보일드미의 물리적, 화학적 및 관능적 특성은 파보일링 과 정중의 침지와 열처리 정도 등 다양한 공정요인이 관여하여 제 조방법에 따라 다르다. 벼의 낱알중에 함유된 전분의 호화는 파 보일링을 통하여 야기되는 가장 중요한 변화인데 쌀알의 투명 도, 도정률, 팽윤성, 용해도, 점성, 열팽창성, 도정후의 비타민, 당, 아미노산 함량 등에 영향을 주는 것으로 보고되고 있다 (Filho, 1986).

올벼쌀은 식량이 부족했던 시절에 수확시기가 늦어지게 되면 이른 가을에 이삭을 채취하여 쪄서 말린 다음 현미로 도정하여 간식용이나 밥으로 섭취하였던 전통 가공쌀 이다(Park 등, 2007). 올벼쌀의 주요공정은 원료 미숙찰벼를 수확하여 세척, 선 별하고 침지(12-24h), 증자(2h), 천일건조(10h), 제현, 현미도정 이며 제조과정은 파보일미와 유사하다.

올벼쌀은 직접 식용이 가능한 호화된 형태의 현미로 쌀의 소 비촉진을 위한 쌀 가공제품으로 기대되는 품목이나 올벼쌀 상 용제품에 대한 영양성분(Lee 등, 2010)과 호화특성(Park 등, 2007) 등 이화학적 특성이 보고되었을 뿐 체계적인 연구는 미 진한 실정이다. 특히, 올벼쌀은 대부분 전래되는 관행방법에 의 존하여 제조되고 있어 품질관리가 제조자의 경험과 숙련에 의 존하는 실정으로 현대적인 제품으로 변화 필요성이 있다. 또한 
파보일링 처리에 의한 쌀의 수화, 조리성, 식미특성, 제품특성 의 변화를 감안할 때 올벼쌀의 품질변화에 미치는 열처리 조건 의 영향 등 구명에 대한 연구가 필요로 된다.

따라서 본 연구에서는 올벼쌀 생산조건을 설정하는 기초연구 로서 올벼쌀의 가공조건이 이화학적 특성 변화에 미치는 영향 을 구명하고자 증자와 건조조건을 달리하여 올벼쌀을 제조하고 올벼쌀의 호화도와 수화 특성 및 경도와 관능적 기호도를 조사 하였다.

\section{재료 및 방법}

올벼쌀의 제조. 쌀은 2009년 군산시 개정면에서 생산된 동진찰 벼를 사용하였으며 탈곡된 벼를 정선하여 $25^{\circ} \mathrm{C}$ 에서 24 시간동안 침지한 후 $95-100^{\circ} \mathrm{C}$ 포화수증기로 60 분(이하 상압증자) 또는 $121^{\circ} \mathrm{C}$ 에서 20 분간 증자(이하 고압증자)한 다음 $45,60,80^{\circ} \mathrm{C}$ 의 열풍을 이용하여 수분함량 $13-15 \%$ 가 되도록 각각 건조하였고 정백비율 95-99\%가 되도록 제현하였다. 전통방식으로 제조된 올벼쌀은 제조이력이 불분명하므로 전통방식과 가장 유사한 24 시간 침지한 다음 상압증자하고 햇볕에서 건조한 올벼쌀을 대 조구로 품질을 비교하였다. 분말시료는 올벼쌀을 분쇄한 후 표 준체(100 mesh)를 통과한 것을 시료로 이용하였다.

호화특성. 아밀로그램 특성은 신속점도측정계(Model RVA-4, Newport Scientific, Australia)를 이용하여 측정하였다. 백미 미 분 $3 \mathrm{~g}$ 과 $25 \mathrm{~mL}$ 을 호화용기에 넣고 $50^{\circ} \mathrm{C}$ 부터 $95^{\circ} \mathrm{C}$ 까지 $12^{\circ} \mathrm{C} /$ $\mathrm{min}$ 의 속도로 상승시킨 후 동일한 속도로 $50^{\circ} \mathrm{C}$ 까지 냉각시키 면서 호화개시온도(Gelatinization Temperature, $\left.{ }^{\circ} \mathrm{C}\right)$, 최고점도 (Peak Viscosity, RVU), 최저점도(Hot Viscosity, RVU), 최종점 도(Cool Viscosity, RVU)를 구한 후 Break Down(최고점도-최 저점도), Consistency(최종점도-최저점도), Set Back(최종점도-최 고점도)을 계산하였다.

경도의 측정. 경도(Hardness)는 상태가 양호한 시료 50개를 선 정하고 Texture analyser(TA-XT, Plus. Stable Micro System, $\mathrm{UK}$ )를 이용하여 쌀알의 중심부를 직경 $\varphi 2 \mathrm{~mm}$ prove 로 눌렀 을 때 얻어지는 힘과 시간의 그래프로부터 산출되는 경도를 표 시하였다.

물결합력. 올벼쌀의 결합력(WBC: water binding capacity)은 Medcalf와 Gilles(1965)의 방법을 변형하여 사용하였다. 시료 $2 \mathrm{~g}$ 에 증류수 $20 \mathrm{~mL}$ 를 가하고 자열자석교반기(SMDS3/6, DaihanSci Co., Korea)를 이용하여 1시간 동안 $200 \mathrm{rpm}$ 으로 교반한 후 $8,000 \mathrm{rpm}$ 으로 30 분간 원심분리(Union 55R, Hanil Science Industrial Co., Korea)하였다. 원심분리후 상등액을 제거하고 침 전물의 무게를 측정하여 처음 시료량과의 중량비로부터 물결합 력을 계산하였다.

팽윤력. 올벼쌀의 팽윤력(SP: swelling power)은 Schoch (1964) 의 방법으로 측정하였다. 항량으로 조정된 원심분리관에 시료 $2.5 \mathrm{~g}$ 을 취하고 증류수 $30 \mathrm{~mL}$ 를 혼합하여 균질하고 $80^{\circ} \mathrm{C}$ 의 진 탕교반기에서 $200 \mathrm{rpm}$ 으로 30 분간 진탕한 다음 원심분리 $(8,000$ $\mathrm{rpm}, 30 \mathrm{~min}$ ) 하여 상등액과 침전물을 분리하였다. 상등액을 증 발접시로 옮겨 $105^{\circ} \mathrm{C}$ 에서 건조하여 중량을 측정하였고 침전물 의 중량은 원심분리관의 중량과의 차이로부터 측정하였으며 다 음식을 이용하여 용해도를 계산하였다.

$$
\begin{aligned}
& \text { 물 결합력 }(\mathrm{WBC}, \%)=\frac{\text { 침전물의 건량 }(\mathrm{g})}{\text { 시료의 건량 }(\mathrm{g})} \times 100 \\
& \text { 팽윤력 }(\mathrm{SP}, \%)=\frac{\text { 침전물의 건량 }(\mathrm{g})}{\text { 시료의 건량 }(\mathrm{g}) \times(100 \text {-용해도 })} \times 100 \\
& \text { 용해도 }(\mathrm{WS}, \%)=\frac{\text { 상등액의 건량 }(\mathrm{g})}{\text { 시료의 건량 }(\mathrm{g})} \times 100
\end{aligned}
$$

관능적 특성. 올벼쌀 일정량을 흰색 사기 용기에 담아 제시하 고 전통적인 올벼쌀의 취식방법에 의거하여 별도의 조리과정 없 이 쌀알을 직접 섭취하도록 하였다. 각 시료 용기에는 난수표 에서 선택한 세 자리 숫자를 표기하였고 관능검사 경험이 있는 패널요원을 선발하여 실험목적 및 검사 세부항목에 대하여 설 명한 다음 검사에 응하도록 하였다. 평가 항목은 외관, 색, 냄 새, 맛, 질감, 종합적 기호도를 평가하였고 평가척도는 9점 척 도법 $(1=$ 대단히 많이 싫어한다, $9=$ 대단히 많이 좋아한다)을 사 용하였다.

\section{결과 및 고찰}

호화특성의 변화. 증자와 건조조건을 달리하여 제조한 올벼쌀의 호화특성은 Table 1 과 같다. 올벼쌀의 최고점도는 $60^{\circ} \mathrm{C}$ 이상의 건조조건에는 고압증자가, $60^{\circ} \mathrm{C}$ 이하에서는 상압증자가 상대적 으로 높았는데 상압증자의 경우 건조온도가 증가할수록 최고점 도가 감소하는 경향을 보였다. 강하점도의 경우에는 상압증자가 고압증자 보다 전반적으로 높았고 이러한 경향은 치반점도와 최 종점도에서도 같은 결과를 보였다. 특히, 상압증자후 천일건조 한 올벼쌀(대조구)은 고압증자후 $60^{\circ} \mathrm{C}$ 로 건조 또는 상압증자후 $45^{\circ} \mathrm{C}$ 건조 보다 최고점도와 강하점도가 낮았고 최종점도와 강 하점도가 상대적으로 낮았다. 최고점도와 강하점도가 높을수록 밥맛은 향상된다는 보고(Won 등, 2005)가 있으며 치반점도는 전분의 노화 경향을 반영하며 최종점도가 높은 값을 나타내는 것은 전분의 결정화가 용이한 노화성이 높다는 것을 시사한다 (Lee 등, 2010). 올벼쌀의 호화개시온도는 $62-63^{\circ} \mathrm{C}$ 범위를 보 여서 증자와 건조조건에 따른 뚜렷한 경향은 없었으나 파보일 링에 의하여 낮아지는 결과를 보였다. Chun 등(2010)은 동진찰 품종의 생쌀의 호화개시온도는 $68^{\circ} \mathrm{C}$ 라고 하였고 Park 등(2007) 은 전통 올벼쌀의 호화개시온도가 생쌀 보다 낮은 값을 나타냈 다고 하여 본 연구와 같은 결과를 보고하였는데 Biliaderis 등 (1981)은 전분의 초기호화온도는 전분입자의 결정에 영향을 받 으며 아밀로펙틴의 분지도가 높을수록 결정성이 낮고 호화온도 를 낮춘다고 설명하고 있다.

물결합력과 팽윤력의 변화. 증자와 건조조건에 따른 올벼쌀의 물결합력과 팽윤력을 측정한 결과를 Fig. 1와 Fig. 2에 각각 나 타냈다. 증자조건에 따른 올벼쌀의 물결합력은 Fig. 1과 같이 고압증자가 높았으며 건조조건에 의한 차이는 전반적으로 유사 한 수준을 보였다. 같은 경향은 올벼쌀의 팽윤력 측정에서도 확 인되었는데 팽윤력도 증자와 건조조건에 의한 큰 차이를 나타 
Table 1 Effect of steaming and dehydration condition on pasting characteristics of Olbyeossal made from rough Waxy rice

\begin{tabular}{|c|c|c|c|c|c|c|c|c|}
\hline $\begin{array}{l}\text { Steaming } \\
\text { condition }\end{array}$ & $\begin{array}{l}\text { Drying } \\
\text { temp. }\end{array}$ & $\begin{array}{l}\text { Viscosity } \\
(\max )\end{array}$ & $\begin{array}{l}\text { Viscosity } \\
\text { (min) }\end{array}$ & Break-down & Viscosity (Final) & Setback & Peak time & $\begin{array}{c}\text { Pasting temp. } \\
\left({ }^{\circ} \mathrm{C}\right)\end{array}$ \\
\hline \multirow{4}{*}{$\begin{array}{l}121^{\circ} \mathrm{C} \\
20 \mathrm{~min}\end{array}$} & $45^{\circ} \mathrm{C}$ & $84.4 \pm 8.77^{a}$ & $63.3 \pm 3.08^{\mathrm{a}}$ & $19.6 \pm 6.24^{\mathrm{a}}$ & $76.0 \pm 3.39^{\mathrm{a}}$ & $14.1 \pm 1.70^{\mathrm{ab}}$ & $2.62 \pm 0.04^{\mathrm{a}}$ & $62.3 \pm 0.05^{\mathrm{a}}$ \\
\hline & $60^{\circ} \mathrm{C}$ & $103.8 \pm 2.90^{\mathrm{b}}$ & $73.3 \pm 1.06^{\mathrm{b}}$ & $30.5 \pm 1.88^{b}$ & $88.5 \pm 1.36^{\mathrm{b}}$ & $15.8 \pm 0.34^{\mathrm{b}}$ & $2.79 \pm 0.07^{\mathrm{a}}$ & $62.3 \pm 0.05^{\mathrm{a}}$ \\
\hline & $80^{\circ} \mathrm{C}$ & $73.0 \pm 15.86^{\mathrm{c}}$ & $53.0 \pm 1.33^{\mathrm{c}}$ & $3.02 \pm 3.24^{\mathrm{c}}$ & $59.3 \pm 16.85^{\mathrm{c}}$ & $11.8 \pm 3.23^{\mathrm{a}}$ & $4.00 \pm 2.63^{b}$ & $63.1 \pm 0.17^{\mathrm{b}}$ \\
\hline & Sun-dried & $34.7 \pm 15.82^{\mathrm{d}}$ & $34.5 \pm 1.56^{\mathrm{d}}$ & $0.19 \pm 0.21^{\mathrm{c}}$ & $31.6 \pm 13.63^{d}$ & $13.7 \pm 2.52^{\mathrm{ab}}$ & $6.80 \pm 0.07^{\mathrm{d}}$ & $63.2 \pm 0.90^{\mathrm{b}}$ \\
\hline \multirow{4}{*}{$\begin{array}{c}95^{\circ} \mathrm{C} \\
60 \mathrm{~min}\end{array}$} & $45^{\circ} \mathrm{C}$ & $152.9 \pm 4.54^{\mathrm{e}}$ & $93.4 \pm 1.75^{\mathrm{e}}$ & $59.5 \pm 6.06^{\mathrm{d}}$ & $122.1 \pm 0.52^{\mathrm{e}}$ & $28.6 \pm 2.22^{c}$ & $2.68 \pm 0.07^{\mathrm{a}}$ & $62.4 \pm 0.02^{\mathrm{a}}$ \\
\hline & $60^{\circ} \mathrm{C}$ & $87.6 \pm 0.38^{a}$ & $74.4 \pm 0.71^{\mathrm{b}}$ & $1.30 \pm 0.33^{\mathrm{c}}$ & $86.9 \pm 2.52^{\mathrm{b}}$ & $15.0 \pm 0.40^{\mathrm{ab}}$ & $5.12 \pm 0.00^{\mathrm{bc}}$ & $62.5 \pm 0.07^{\mathrm{a}}$ \\
\hline & $80^{\circ} \mathrm{C}$ & $51.0 \pm 4.63^{f}$ & $47.6 \pm 3.77^{\mathrm{f}}$ & $3.44 \pm 0.85^{\mathrm{c}}$ & $59.4 \pm 4.81^{\mathrm{c}}$ & $11.8 \pm 1.04^{\mathrm{a}}$ & $5.84 \pm 0.25^{\mathrm{cd}}$ & $63.2 \pm 0.90^{\mathrm{b}}$ \\
\hline & Sun-dried & $116.0 \pm 5.17^{\mathrm{g}}$ & $87.9 \pm 2.56^{\mathrm{g}}$ & $26.6 \pm 7.78^{b}$ & $111.1 \pm 2.30^{\mathrm{f}}$ & $24.5 \pm 5.03^{\mathrm{d}}$ & $4.63 \pm 0.15^{\mathrm{b}}$ & $62.5 \pm 0.05^{\mathrm{a}}$ \\
\hline
\end{tabular}

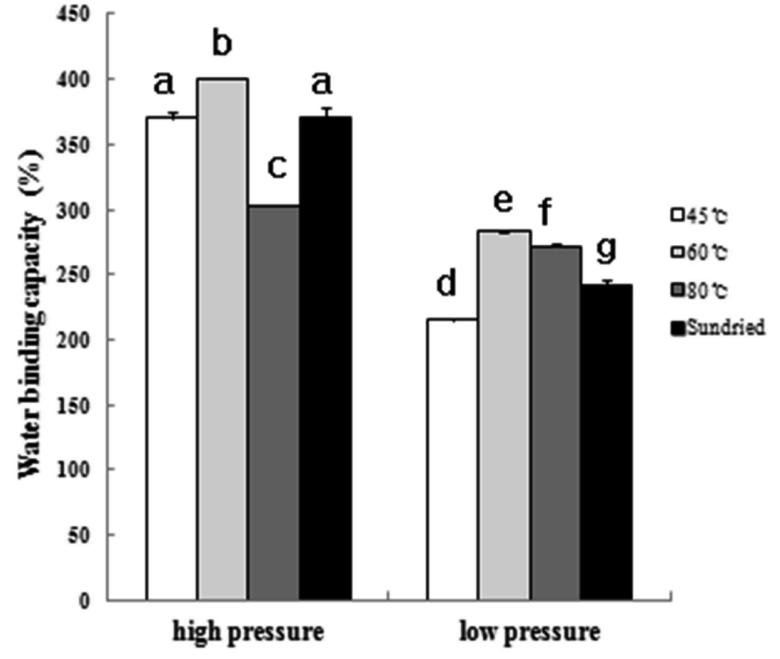

Fig. 1 Effect of steaming and dehydration condition on water binding capacity of Olbyeossal made from rough Waxy rice

내지 않았다. 상압증자후 천일건조한 올벼쌀(대조구)은 상압증 자후 $45^{\circ} \mathrm{C}$ 로 건조한 올벼쌀을 제외한 다른 조건보다 낮아서 개 선된 방식의 올벼쌀에 비하여 수화성이 낮은 결과를 나타냈다. 이러한 결과는 올벼쌀의 수분흡수가 다른 현미에 비하여 현저 하게 높았다는 Park 등(2007)의 보고와 유사한 경향이며 전분 의 호화로 인한 쌀의 결정구조가 파괴되어 물 분자와의 수소결 합이 쉽게 형성(Meuser 등, 1978)된 것으로 생각된다. 한편 Pressure parboiling한 쌀은 다른 방법으로 파보일링한 쌀 보다 수화력이 감소한다는 보고(Park과 Cho, 1995)도 있으나 이는 적 용된 실험조건의 상이함으로 호화정도에서 차이가 나타난 것으 로 사료된다. 전분입자의 수분결합력은 전분의 손상도가 많을수 록 높아지는 것으로 알려져 있으며(Choi 등, 2001; Chang과 Yeh, 2002), 전분입자의 내부 치밀도가 낮은 경우 수분흡수가 크다는 Halick과 Kelly (1959)의 보고도 있다. 또한 Wong과 Lelieve (1982)는 전분의 팽윤력은 전분입자내의 결정성과 상관 성을 갖는다고 하였고 Leach 등(1959)은 온도에 따른 전분의 팽윤양상은 전분입자의 내부 결합력과 회합 정도에 따라서 차 이가 있으며 결합정도가 강한 전분은 팽윤에 대해 강하게 저항 하기 때문에 팽윤력을 비교하면 상대적인 결합강도를 알 수 있 다 보고한 바 있다.

경도의 변화. 올벼쌀의 경도는 최종 수분함량이 주요영향인자이 며 올벼쌀과 유사한 파보일미의 경도는 가공 중 증가하는 것으

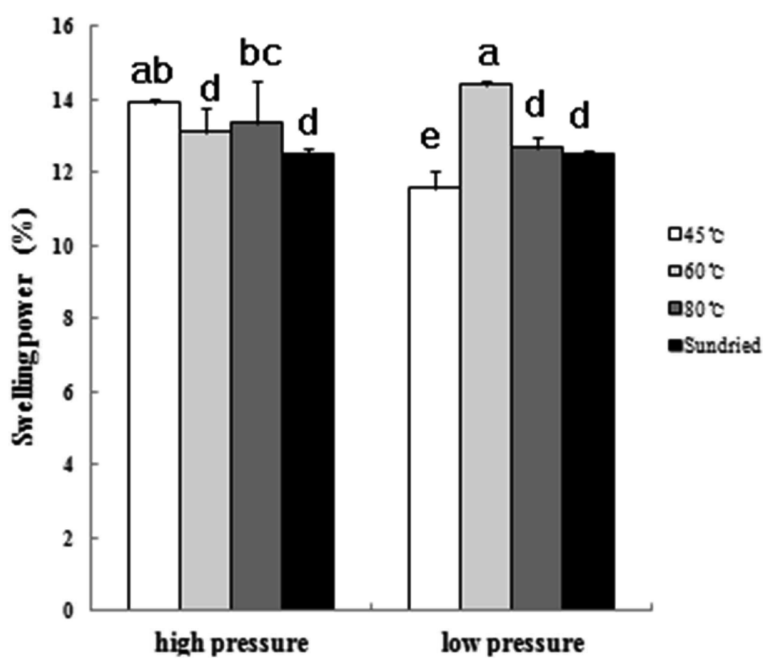

Fig. 2 Effect of steaming and dehydration condition on swelling power of Olbyeossal made from rough Waxy rice

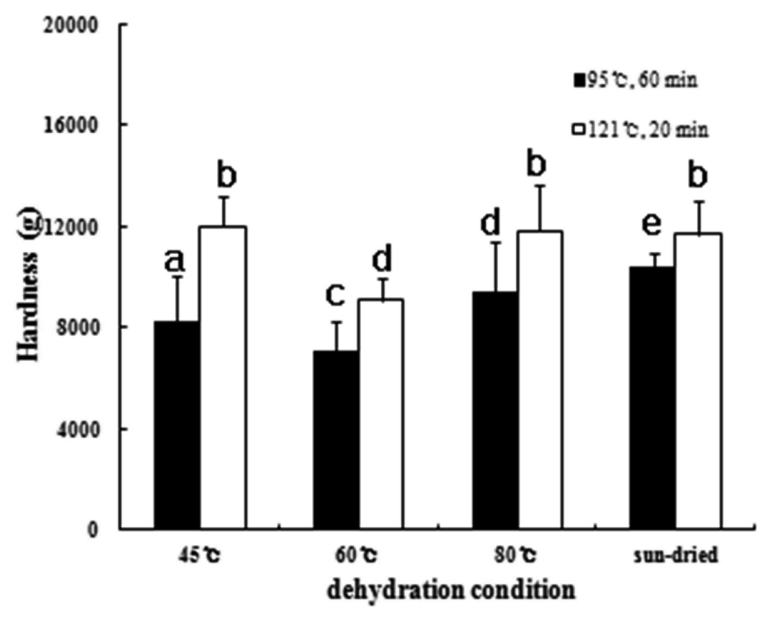

Fig. 3 Effect of steaming and dehydration condition on hardness of Olbyeossal made from rough Waxy rice

로 기 보고된 바 있다(Qureshi 등, 2000). 증자방법과 건조조건 을 달리하여 제조한 올벼쌀의 경도를 측정한 결과는 Fig. 3과 같다. 고압증자한 경우 올벼쌀의 경도는 9-12 kg 범위이고 상 압증자한 올벼쌀은 7-10 kg 수준으로 나타나서 고압증자조건에 서 전반적으로 높은 경도를 보였는데 올벼쌀의 경도가 $10.5 \mathrm{~kg}$ 
Table 2 Effect of steaming condition on sensory characteristics of Olbyeossal made from rough Waxy rice

\begin{tabular}{|c|c|c|c|c|c|c|}
\hline Steaming condition & Appearance & Color & Flavour & Taste & Texture & Overall acceptability \\
\hline Commercial product & $5.3 \pm 1.4^{\mathrm{a}}$ & $5.3 \pm 1.5^{\mathrm{a}}$ & $4.9 \pm 1.5^{\mathrm{a}}$ & $4.8 \pm 2.2^{\mathrm{a}}$ & $4.3 \pm 2.4^{\mathrm{a}}$ & $4.3 \pm 1.5^{\mathrm{a}}$ \\
\hline $95^{\circ} \mathrm{C}, 60 \mathrm{~min}$ & $5.8 \pm 1.9^{\mathrm{a}}$ & $5.6 \pm 1.9^{a}$ & $5.1 \pm 2.0^{\mathrm{a}}$ & $4.6 \pm 1.9^{\mathrm{a}}$ & $3.6 \pm 1.9^{\mathrm{a}}$ & $4.3 \pm 1.8^{\mathrm{a}}$ \\
\hline $121^{\circ} \mathrm{C}, 20 \mathrm{~min}$ & $5.1 \pm 2.2^{\mathrm{a}}$ & $5.4 \pm 2.1^{\mathrm{a}}$ & $6.1 \pm 1.3^{\mathrm{a}}$ & $5.4 \pm 1.8^{\mathrm{a}}$ & $4.3 \pm 3.0^{\mathrm{a}}$ & $4.6 \pm 2.2^{\mathrm{a}}$ \\
\hline
\end{tabular}

*Commercial product was sun-dried after steaming at $95^{\circ} \mathrm{C}$ and other samples were dried at $80^{\circ} \mathrm{C}$ after steaming under suggested condition, respectively.

Table 3 Effect of dehydration condition on sensory characteristics of Olbyeossal made from rough Waxy rice

\begin{tabular}{|c|c|c|c|c|c|c|}
\hline Dehydration condition & Appearance & Color & Flavour & Taste & Texture & Overall acceptability \\
\hline Commercial product & $4.4 \pm 1.5^{\mathrm{a}}$ & $3.9 \pm 1.3^{\mathrm{a}}$ & $4.5 \pm 1.1^{\mathrm{a}}$ & $4.1 \pm 1.0^{\mathrm{a}}$ & $4.1 \pm 2.0^{\mathrm{a}}$ & $3.6 \pm 1.3^{\mathrm{a}}$ \\
\hline $45^{\circ} \mathrm{C}$ & $5.8 \pm 1.7^{\mathrm{b}}$ & $5.6 \pm 1.6^{\mathrm{b}}$ & $5.1 \pm 1.0^{\mathrm{a}}$ & $5.0 \pm 1.6^{\mathrm{a}}$ & $4.4 \pm 2.5^{\mathrm{a}}$ & $4.8 \pm 2.0^{\mathrm{a}}$ \\
\hline $60^{\circ} \mathrm{C}$ & $5.6 \pm 1.7^{b}$ & $5.7 \pm 1.7^{\mathrm{b}}$ & $5.1 \pm 1.2^{\mathrm{a}}$ & $4.6 \pm 1.4^{\mathrm{a}}$ & $3.9 \pm 2.1^{\mathrm{a}}$ & $4.4 \pm 1.7^{\mathrm{a}}$ \\
\hline $80^{\circ} \mathrm{C}$ & $5.5 \pm 1.5^{\mathrm{ab}}$ & $5.8 \pm 1.5^{b}$ & $5.1 \pm 1.3^{\mathrm{a}}$ & $5.3 \pm 1.9^{\mathrm{a}}$ & $4.3 \pm 2.5^{\mathrm{a}}$ & $4.8 \pm 1.9^{\mathrm{a}}$ \\
\hline Sun-dried & $5.5 \pm 0.9^{\mathrm{ab}}$ & $5.4 \pm 1.2^{\mathrm{b}}$ & $4.8 \pm 1.1^{\mathrm{a}}$ & $4.8 \pm 1.8^{\mathrm{a}}$ & $3.1 \pm 2.2^{\mathrm{a}}$ & $4.3 \pm 1.6^{\mathrm{a}}$ \\
\hline
\end{tabular}

*Commercial product was sun-dried after steaming at $95^{\circ} \mathrm{C}$ and other samples were steamed at $121^{\circ} \mathrm{C}$ for 20 min and then dried under suggested condition, respectively.

수준인(Park 등, 2007)과 Lee 등(2010)의 보고와 차이가 있었다. 또한 열풍건조 온도가 높을수록 올벼쌀의 경도는 증가하는 경 향을 보였는데 이와 같은 결과는 올벼쌀의 경도는 건조 소요시 간 보다 증자조건과 건조온도가 영향인자임을 시사한다. 특히, 전통방식의 올벼쌀에서 적용되는 천일건조는 증자조건에 관계 없이 시험된 모든 조건에서 가장 높은 경도 값을 보였는데 올 벼쌀의 품질향상을 위해서는 천일건조를 지양해야 할 것으로 생 각되며 Park 등(2007)은 딱딱한 조직감을 전통 올벼쌀의 문제 점으로 지적한 바 있다. 파보일미의 건조과정에서 상대적으로 높은 온도에서의 열풍건조는 쌀의 변색과 동할미나 쇄미 발생 을 촉진한다고 알려져 있다(Srinivasa Rao 등, 2007). 올벼쌀은 열처리 과정을 거친 가공 쌀로써 부패나 변질을 방지할 목적하 에 수분함량을 $12.7 \%$ 이하로 건조하여 경도값이 매우 높은 것 으로 판단된다(Lee 등, 2010).

관능적 특성의 변화. 증자조건이 올벼쌀의 관능적 품질 변화에 미치는 영향을 Table 2에 나타내었다. 외관과 색상은 상압증자 한 올벼쌀이 고압증자한 시료 보다 높은 점수를 보였다. 반면 냄새, 맛, 조직감 및 전반적 기호도는 고압증자한 올벼쌀이 상 압증자한 것보다 높은 기호도를 보였는데 Chang과 Hwang (1988)은 취반기구에 따른 밥의 식미평가에서 전기밥솥으로 취 반할 때 보다 압력밥솥으로 취반하면 식미가 좋아진다고 보고 한 바 있다. 상기 결과를 바탕으로 고압조건에서 증자한 다음 건조온도를 달리하여 제조한 올벼쌀의 관능적 특성은 Table 3 과 같다. 모든 처리구에서 통계적 유의성은 없었으나 $(p<0.05)$ 올벼쌀의 관능적 특성은 건조온도에 따라 차이를 보이는 것으 로 나타났다. 외관과 조직감은 $45^{\circ} \mathrm{C}$ 열풍건조를 가장 선호하는 것으로 나타났고 $80^{\circ} \mathrm{C}$ 의 열풍으로 건조한 올벼쌀은 색상과 맛 이 우수한 것으로 평가되었다. 종합적인 전반적 기호도는 $45^{\circ} \mathrm{C}$ 와 $80^{\circ} \mathrm{C}$ 의 열풍으로 건조한 올벼쌀이 다른 조건에 비하여 점수 가 높았는데 색상 등 외관과 맛의 조화가 높을수록 올벼쌀의 식감을 좋게 하는 것으로 생각된다. 결과적으로 올벼쌀의 관능 적 특성은 고압증자한 다음 $45^{\circ} \mathrm{C}$ 와 $80^{\circ} \mathrm{C}$ 의 열풍건조 조건을 선 호하는 것으로 나타났고 상압증자한 다음 햇볕에서 건조한 전 통방식의 올벼쌀 보다 관능적 기호도가 높았다.

\section{초 록}

증자 및 건조조건을 달리하여 올벼쌀을 제조하고 호화도, 물결 합력, 팽윤력, 및 경도 및 관능적 기호도의 변화를 시험하였다. 원료는 동진찰벼를 사용하였으며 탈곡된 벼를 24시간 수침한 다음 $95-100^{\circ} \mathrm{C}$ 에서 60 분 또는 $121^{\circ} \mathrm{C}$ 에서 20 분간 증자하였고 $45,60,80^{\circ} \mathrm{C}$ 의 열풍과 햇볕을 이용하여 수분함량 $13-15 \%$ 가 되도록 각각 건조하여 준비하였다. 올벼쌀의 호화개시온도는 생 쌀 보다 낮았으며 상압증자 후 $45-60^{\circ} \mathrm{C}$ 의 열풍으로 건조한 올 벼쌀은 최고점도, 강하점도, 치반점도, 최종점도가 다른 가공조 건에 비하여 높았다. 올벼쌀의 수분결합력과 팽윤력은 고압증자 가 상압증자보다 높았으며 건조조건에 따른 유의적인 차이는 없 었다. 올벼쌀의 경도는 고압증자조건에서 건조온도가 높을수록 올벼쌀의 경도는 증가하는 경향을 보였다. 올벼쌀에 대한 관능 검사 결과는 고압에서 증자한 다음 $45^{\circ} \mathrm{C}$ 와 $80^{\circ} \mathrm{C}$ 의 열풍으로 건 조한 올벼쌀이 외관, 색상, 맛, 전반적 기호도가 우수한 것으로 나타났다. 이와 같은 결과는 증자와 건조조건이 올벼쌀의 품질 을 좌우하는 영향인자로서 중요성을 나타낸다.

Keywords 올벼쌀·증자·건조·이화학적 특성 - 관능적 특성

감사의 글 본 연구는 농촌진흥청 국립농업과학원 농업과학기술 연구개발사 업(과제번호 PJ007172052011)의 지원에 의해 이루어진 것이며 이에 깊은 감 사를 드립니다.

\section{참고문헌}

Bhattacharya KR (1977) Breakage of rice during milling A review. Trop Sci 22, 255-76.

Biliaderis, GC, Grant, DR, and Bose JR (1981) Studies on amylose, amylopectin and beta-limit dextrins. Creal Chem 58, 496-9.

Burn EE (1972) Canned rice foods, In Rice: Chemistry and Technology, Houston DF (ed.), vol. 1, pp 419-27. American Association of Cereal Chemists Inc., USA.

Chang IY and Hwang IK (1988) A study of physicochemical analysis and sensory evaluation for cooked rices made by several cooking method (II) 
- Especially for warm and cool cooked rices. Korean J Soc Food Sci 4, 51-6.

Chang PY and Yeh AI (2002) Effect of soaking on wet-milling of rice. $J$ Cereal Sci 35, 85-94.

Choi CR, Kim JO, Lee SK, and Shin MS (2001) Properties of fractions from waxy rice flour classified with particle size. Food Sci Biotechnol 10, 54 8.

Chun AR, Kim DJ, Yoon MR, Oh SK, Hong AC, Choi IS et al. (2010) Variation in quality and preference of sogokju (Korean Traditional rice wine) from waxy rice varieties Korean J Crop Sci 55, 177-86.

Filho SS (1986) Economic and social benefits of rice parboiling. Lavoura Arroz 39, 19-26.

Gariboldi F (1974) Rice parboiling: FAO agricultural development. Vol. 97, pp. 1-97, Food and Agricultural Organization of the United Nations, Rome, Italy.

Halick JV and Kelly VJ (1959) Gelatinization and pasting characteristics of rice varieties as related to cooking behavior. Cereal Chem 36, 91-8.

Leach HW, McCowen LD, and Schoch TJ (1959) Structure of the starch granule. I. Swelling and solubility pattern of various starches. Creal Chem 35, 534-44.

Lee MK, Park JS, and Na HS (2010) Physicochemical properties of Olbyeossal. Korean J Food Preserv 17, 208-13.
Medcalf F and Gilles KA (1965) Wheat starches. I. Comparison of physicochemical propertie. Cereal Chem 42, 558-68.

Meuser F, Klingler RW, and Niediek EK (1978) Characterization of mechanically modified starch. Starch 30, 376-84.

Park JD, Choi BK, Kum JS, and Lee HY (2007) Quality and pasting properties of traditional Olbyeossal. Korean J Food Preserv 14, 276-80.

Park SH and Cho EJ (1995) Physical and cooking characteristic properties of parboiled rice. Korean J Soc Food Sci 11, 126-32.

Qureshi AA, Mo H, Packer L, and Peterson DM (2000) Isolation and identification of novel tocotrienols from rice bran with hypocholesterolemic, antioxidant and antitumor properties. J Agric Food Chem 48, 3130-40.

Schoch TJ (1964) Swelling power and solubility of granular strarches. Carbohydrate Chem 4, 106-8.

Srinivasa Rao P, Bal Satish, and Goswami TK (2007) Modelling and optimization of drying variables in thin layer drying of parboiled paddy. J Food Eng 78, 480-7.

Wong RBK and Lelieve J (1982) Comparison of the crystallinties of wheat starches with different swelling capacitie. Starch 34, 159-61.

Won JG, Ahn DJ, Kim SJ Park SD, Choi KB, Lee SC et al. (2005) Comparison of grain quality between chinese parboiled and domestic rice. Korean J Crop Sci 50, 19-23. 